\title{
Croton gratissimus leaf extracts inhibit cancer cell growth by inducing caspase 3/7 activation with additional anti-inflammatory and antioxidant activities
}

\author{
Emmanuel Mfotie Njoya ${ }^{1,2^{*}}$ (D, Jacobus N. Eloff ${ }^{1}$ and Lyndy J. McGaw ${ }^{1}$
}

\begin{abstract}
Background: Croton species (Euphorbiaceae) are distributed in different parts of the world, and are used in traditional medicine to treat various ailments including cancer, inflammation, parasitic infections and oxidative stress related diseases. The present study aimed to evaluate the antioxidant, anti-inflammatory and cytotoxic properties of different extracts from three Croton species.

Methods: Acetone, ethanol and water leaf extracts from C. gratissimus, C. pseudopulchellus, and C. sylvaticus were tested for their free radical scavenging activity. Anti-inflammatory activity was determined via the nitric oxide (NO) inhibitory assay on lipopolysaccharide (LPS)-stimulated RAW 264.7 macrophages, and the 15-lipoxygenase inhibitory assay using the ferrous oxidation-xylenol orange assay. The cytotoxicity of the extracts was determined on four cancerous cell lines (A549, Caco-2, HeLa, MCF-7), and a non-cancerous African green monkey (Vero) kidney cells using the tetrazolium-based colorimetric (MTT) assay. The potential mechanism of action of the active extracts was explored by quantifying the caspase-3/- 7 activity with the Caspase-Glo ${ }^{\oplus} 3 / 7$ assay kit (Promega).
\end{abstract}

Results: The acetone and ethanol leaf extracts of C. pseudopulchellus and C. sylvaticus were highly cytotoxic to the non-cancerous cells with $\mathrm{LC}_{50}$ varying between 7.86 and $48.19 \mu \mathrm{g} / \mathrm{mL}$. In contrast, the acetone and ethanol extracts of $C$. gratissimus were less cytotoxic to non-cancerous cells and more selective with $L_{50}$ varying between 152.30 and $462.88 \mu \mathrm{g} / \mathrm{mL}$, and selectivity index (SI) ranging between 1.56 and 11.64. Regarding the anti-inflammatory activity, the acetone leaf extract of $C$. pseudopulchellus had the highest NO inhibitory potency with an $\mathrm{IC}_{50}$ of 34 . $64 \mathrm{\mu g} / \mathrm{mL}$, while the ethanol leaf extract of the same plant was very active against 15-lipoxygenase with an $\mathrm{IC}_{50}$ of $0.57 \mu \mathrm{g} / \mathrm{mL}$. A linear correlation $(r<0.5)$ was found between phytochemical contents, antioxidant, anti-inflammatory and cytotoxic activities of active extracts. These extracts induced differentially the activation of caspases -3 and -7 enzymes in all the four cancerous cells with the highest induction (1.83-fold change) obtained on HeLa cells with the acetone leaf extract of $C$. gratissimus.

Conclusion: Based on their selective toxicity, good antioxidant and anti-inflammatory activities, the acetone and ethanol leaf extracts of $C$. gratissimus represent promising alternative sources of compounds against cancer and other oxidative stress related diseases.

Keywords: Croton gratissimus, Free radicals, Nitric oxide, 15-lipoxygenase, Cytotoxicity, Caspases

\footnotetext{
* Correspondence: mfotiefr@yahoo.fr

'Phytomedicine Programme, Department of Paraclinical Sciences, Faculty of

Veterinary Science, University of Pretoria, Private Bag X04, Onderstepoort, Pretoria 0110, South Africa

${ }^{2}$ Department of Biochemistry, Faculty of Science, University of Yaoundé I,

P.O. Box 812, Yaoundé, Cameroon
}

(c) The Author(s). 2018 Open Access This article is distributed under the terms of the Creative Commons Attribution 4.0 International License (http://creativecommons.org/licenses/by/4.0/), which permits unrestricted use, distribution, and reproduction in any medium, provided you give appropriate credit to the original author(s) and the source, provide a link to the Creative Commons license, and indicate if changes were made. The Creative Commons Public Domain Dedication waiver (http://creativecommons.org/publicdomain/zero/1.0/) applies to the data made available in this article, unless otherwise stated. 


\section{Background}

Oxidative stress results from an imbalance between the production of free radicals and the ability of the body to counteract or detoxify their harmful effects through neutralization by antioxidants [1]. The free radical theory of aging developed by Denham Harman is based on the concept that damage accumulates throughout the entire lifespan and causes age dependent disorders including diabetes, atherosclerosis, neurodegenerative diseases and cancer [2, 3]. Cancer development is characterized by redox imbalance with a shift towards oxidative conditions. In fact, free radicals can bind through electron pairing with macromolecules such as proteins, phospholipids and DNA in normal cells to cause protein and DNA damage along with lipid peroxidation [1]. Consequently, the accumulation of these cellular disorders may cause mutation and lead to various disturbances in the cell metabolism, which can result in deregulated cell growth, and finally carcinoma [4]. Antioxidants are helpful in reducing and preventing damage caused by free radicals because of their ability to donate electrons, which neutralize the radicals without forming another. This property has led to the hypothesis that antioxidants, with their ability to decrease the level of free radicals, might lessen the radical damage causing chronic diseases, and even radical damage responsible for aging and cancer. Antioxidant phytochemicals found in vegetables, fruits and medicinal plants have been reported to be responsible for health benefits such as the prevention and treatment of chronic diseases caused by oxidative stress [5]. Many antioxidant phytochemicals have been associated with anti-cancer activities, and this includes curcumin from turmeric, genistein from soybean, tea polyphenols from green tea, resveratrol from grapes, sulforaphane from broccoli, isothiocyanates from cruciferous vegetables, silymarin from milk thistle, diallyl sulfide from garlic, lycopene from tomato, rosmarinic acid from rosemary, apigenin from parsley, and gingerol from gingers [6].

During the last two decades, it has been revealed that oxidative stress can lead to chronic inflammation, which in turn could mediate most chronic diseases including cancer. Chronic inflammation is usually associated with an increased risk of several human cancers [7]. Indeed, the relationship between inflammation and cancer has been suggested by epidemiological and experimental data, and confirmed by the fact that anti-inflammatory therapies were also efficient in cancer prevention and treatment $[8,9]$.

The genus Croton belongs to the family Euphorbiaceae, and is a diverse and complex group of plants ranging from herbs and shrubs to trees. Croton species can be found in different parts of the world, and some of the most popular uses include treatment of cancer, constipation, diabetes, digestive problems, dysentery, external wounds, intestinal worms, pain, ulcers and weight loss
[10]. Croton sylvaticus Hochst. is a fast-growing and decorative tree, which is widely used in the management of inflammatory conditions, infections and oxidative stress related diseases. In Tanzania and Kenya, the decoction of the leaves and root bark of C. sylvaticus is used in traditional medicine against tuberculosis (TB), inflammation, as a purgative, as a wash for body swelling caused by kwashiorkor or by tuberculosis, and for the treatment of malaria [11]. Previous reports showed the acetylcholinesterase inhibitory activity of the ethyl acetate leaf extract of $C$. sylvaticus and isolated compounds [12]. Other compounds isolated from this plant have antiplasmodial activity [13], and low to high toxicity observed in the brine shrimp larval lethality test [11]. Croton gratissimus Burch. (synonym $C$. zambesicus Müll.Arg.) is native to tropical west and central Africa, and is used to treat fever, dysentery and convulsions [14]. The leaf decoction is used in Benin as anti-hypertensive, anti-microbial (against urinary infections) and to treat malaria-linked fever [15]. Some compounds, named cembranolides isolated from leaf extracts of Croton gratissimus, have moderate activity against ovarian cancer cell lines and Plasmodium falciparum [16, 17]. Croton pseudopulchellus Pax, originating from southern Africa, is widely distributed in tropical East and West Africa. This Croton species is used in southern and central parts of South Africa against TB symptoms such as coughs, fever and blood in sputum [18]. Based on their diverse uses in traditional medicine against various diseases in which excess production of free radicals or inflammation is implicated, the present study aims to evaluate the antioxidant, anti-inflammatory and cytotoxic properties of three Croton species extracted using different solvents.

\section{Materials and methods}

\section{Plant material and extraction}

Fresh leaves of the three Croton species were collected at the Lowveld Botanical Gardens, Nelspruit, Mpumalanga (South Africa) in January 2016. The plant materials were dried at room temperature in a well-ventilated room for two weeks. The dried materials were ground to fine powder and stored in honey jars in the dark until use. Herbarium specimens for each of the plant species were prepared, and identification was made by Mrs. Elsa van Wyk and Ms. Magda Nel of the HGWJ Schweickerdt Herbarium (PRU), University of Pretoria. The identification numbers of plant species are presented in Table 1. Powder $(100 \mathrm{~g})$ from each plant was extracted by maceration in $1000 \mathrm{~mL}$ of different solvents (water, acetone and ethanol). The mixtures were covered and left overnight at room temperature. Each mixture was filtered through Whatman No.1 filter paper into pre-weighed honey jars and the filtrates obtained from acetone and ethanol extraction were concentrated under reduced pressure using a rotary evaporator at $40^{\circ} \mathrm{C}$ to obtain a residue which 
Table 1 Herbarium specimen identification and yield of crude extracts from the three Croton species

\begin{tabular}{|c|c|c|c|c|c|}
\hline \multirow[t]{2}{*}{ Plant name } & \multirow[t]{2}{*}{ Family name } & \multirow{2}{*}{$\begin{array}{l}\text { Herbarium } \\
\text { specimen } \\
\text { no. }\end{array}$} & \multicolumn{3}{|c|}{ Yield of extraction (\%) } \\
\hline & & & Water & Acetone & Ethanol \\
\hline Croton gratissimus Burch. & Euphorbiaceae & $\mathrm{PRU} / 122516$ & 3.29 & 5.15 & 6.23 \\
\hline Croton pseudopulchellus Pax & Euphorbiaceae & $\mathrm{PRU} / 122519$ & 4.65 & 7.63 & 8.95 \\
\hline Croton sylvaticus Hochst. & Euphorbiaceae & $\mathrm{PRU} / 122523$ & 4.11 & 6.18 & 7.59 \\
\hline
\end{tabular}

constituted the crude extract. The water filtrate was dried in a ventilated oven at $50-55^{\circ} \mathrm{C}$ until complete evaporation of water. The extraction process was repeated three times with fresh solvent. The honey jars containing the crude extracts were weighed again to determine the percentage yield of the crude extracts (Table 1). The dried extracts were stored in a cold room $\left(4{ }^{\circ} \mathrm{C}\right)$ until use.

\section{Phytochemical analysis Total phenolic content}

The total phenolic content (TPC) of different extracts was determined using the Folin-Ciocalteu method adapted to a 96-well microplate as described by Zhang et al. [19]. The reaction mixture was prepared by adding respectively $20 \mu \mathrm{L}$ of each extract ( $5 \mathrm{mg} / \mathrm{mL}$ in DMSO), $100 \mu \mathrm{L}$ of Folin-Ciocalteu reagent $(1 \mathrm{~mL}$ of Folin-Ciocalteu reagent in $9 \mathrm{~mL}$ of distilled water), and $80 \mu \mathrm{L} 7.5 \% \mathrm{Na}_{2} \mathrm{CO}_{3}$ solution in deionized water. The mixture was then incubated in the dark at room temperature $\left(25^{\circ} \mathrm{C}\right)$ for $30 \mathrm{~min}$, and the absorbance was read at $765 \mathrm{~nm}$ on a microplate reader (Epoch, BioTek). The total phenolic content was estimated from a gallic acid (GA) calibration curve $\left(10-100 \mathrm{mg} / \mathrm{L} ; y=0.6886 x+0.0884 ; R^{2}=\right.$ 0.9901), and results were expressed as milligram of gallic acid equivalent (GAE) per gram of extract.

\section{Total flavonoid content}

The total flavonoid content (TFC) of different extracts was determined using the aluminium chloride spectrophotometric method based on the formation of aluminium-flavonoid complexes [20]. The reaction mixture was prepared by mixing $2 \mathrm{~mL}$ of each extract $(0.3 \mathrm{mg}$ in $1 \mathrm{~mL}$ of methanol), $0.1 \mathrm{~mL}$ of aluminium chloride hexahydrate solution ( $10 \%$ aqueous $\mathrm{AlCl}_{3}$ solution), $0.1 \mathrm{~mL}$ of $1 \mathrm{M}$ potassium acetate and $2.8 \mathrm{~mL}$ of deionized water. The mixture was shaken and incubated at room temperature $\left(25^{\circ} \mathrm{C}\right)$ for 10 min, and $200 \mu \mathrm{L}$ of each mixture was transferred to 96-well microplate. The absorbance was measured at $415 \mathrm{~nm}$ using a microplate reader (Epoch, BioTek). A calibration curve was plotted from the absorbance of quercetin $\quad(0.005-0.1 \mathrm{mg} / \mathrm{mL} ; y=9.0545 x-0.0142$; $\left.R^{2}=0.9999\right)$, and the total flavonoid content was expressed as milligram of quercetin equivalent (QE) per gram of extract.

\section{Antioxidant assays}

\section{The 2,2-diphenyl-1-picrylhydrazyl (DPPH) assay}

The technique described by Brand-Williams et al. [21] with some modifications was applied for the determination of the DPPH scavenging capacity of extracts. Briefly, the extracts $(40 \mu \mathrm{L})$ were serially diluted with methanol on a 96-well plate, followed by the addition of the DPPH solution $(160 \mu \mathrm{L})$ prepared at $25 \mu \mathrm{g} / \mathrm{mL}$. The mixture was incubated at room temperature in the dark for $30 \mathrm{~min}$ and the absorbance was measured at $517 \mathrm{~nm}$ using a microplate reader (Epoch, BioTek). Ascorbic acid and trolox were used as positive controls, methanol plus DPPH as negative control, and sample without DPPH as blank. The DPPH scavenging capacity was calculated at each concentration according to the formula (1) below:

$$
\begin{aligned}
& \text { Scavenging capacity }(\%) \\
& =\frac{\text { Absorbance }(\text { control)-Absorbance }(\text { sample })}{\text { Absorbance }(\text { control })} \times 100
\end{aligned}
$$

The inhibitory concentration $\left(\mathrm{IC}_{50}\right)$ was determined by plotting a non-linear curve of percentage DPPH scavenging capacity against the logarithm of different concentrations of the extract.

\section{The 2,2'-azino-bis (3-ethylbenzothiazoline-6-sulfonic acid) (ABTS) assay}

The method described by Re et al. [22] with some modifications was used for the determination of the ABTS radical scavenging capacity of the extracts. Firstly, the reaction solution was prepared by mixing a solution of ABTS $(7 \mathrm{mM})$ with a solution of potassium persulfate $(2.45 \mathrm{mM})$ at room temperature for 12 to $16 \mathrm{~h}$. The optical density of the reaction solution containing the ABTS radical produced was calibrated to $0.70 \pm 0.02$ at $734 \mathrm{~nm}$ before use. Secondly, the extracts $(40 \mu \mathrm{L})$ were serially diluted with methanol, followed by the addition of the ABTS radical $(160 \mu \mathrm{L})$, and the optical density was measured after $5 \mathrm{~min}$ at $734 \mathrm{~nm}$ using a microplate reader (Epoch, BioTek). Two positive controls (trolox and ascorbic acid) were used. Methanol plus ABTS radical was used as negative control while extract without ABTS was considered as the blank. The percentage of 
ABTS scavenging capacity was calculated at each concentration according to the formula (1) above, and the inhibitory concentrations $\left(\mathrm{IC}_{50}\right)$ values were determined as indicated in the previous paragraph.

\section{Anti-inflammatory assays Nitric oxide inhibitory assay}

The method published by Dzoyem and Eloff [23] was used to determine the nitric oxide inhibitory activity of the extracts. The RAW 264.7 macrophages were obtained from the American Type Culture Collection (ATCC) (Rockville, MD, USA), and were grown at $37^{\circ} \mathrm{C}$ with $5 \% \mathrm{CO}_{2}$ in a humidified environment in Dulbecco's Modified Eagle's Medium (DMEM) high glucose $(4.5 \mathrm{~g} / \mathrm{L})$ containing L-glutamine (4 $\mathrm{mM})$ and sodium pyruvate (Hyclone $\left.{ }^{\mathrm{Tm}}\right)$ supplemented with $10 \%(v / v)$ fetal bovine serum (Capricorn Scientific Gmbh, South America) and 1\% penicillin-streptomycin-fungizone (PSF). Nitric oxide (NO) production by RAW 264.7 macrophages was measured using the Griess reagent (Sigma Aldrich, Germany) after $24 \mathrm{~h}$ of lipopolysaccharide (LPS) stimulation in the presence or absence of the extracts or quercetin used as positive control. Briefly, the RAW 264.7 macrophages were inoculated at a density of $2 \times 10^{4}$ cells per well in 96 well-microtitre plates, and the cells were left overnight to allow attachment to the bottom of the plate. The cells were treated with different concentrations of the extracts dissolved in DMSO with the final concentration of DMSO not exceeding $0.5 \%$. Thereafter, the cells were stimulated by addition of LPS at a final concentration of $1 \mu \mathrm{g} / \mathrm{mL}$ per well. The cells treated with only LPS were considered as the negative control. After $24 \mathrm{~h}$ of incubation at $37^{\circ} \mathrm{C}$ with $5 \% \mathrm{CO}_{2}$ in a humidified environment, the supernatant $(100 \mu \mathrm{L})$ from each well of the 96-well microtitre plates were transferred into new 96-well microtitre plates, and an equal volume of Griess reagent (Sigma Aldrich, Germany) was added. The mixture was left in the dark at room temperature for $15 \mathrm{~min}$, and the absorbance was determined at $550 \mathrm{~nm}$ on a microplate reader (Synergy Multi-Mode Reader, BioTek). The quantity of nitrite was determined from a sodium nitrite standard curve. The percentage of NO inhibition was calculated based on the ability of each extract to inhibit nitric oxide production by RAW 264.7 macrophages compared with the control (cells treated with LPS without extract). In addition, the cell viability was determined using the 3-(4,5-dimethythiazol- 2-yl)-2,5-diphenyl tetrazolium bromide (MTT) assay [24]. The culture medium was aspirated from the plates, and replaced by fresh medium $(200 \mu \mathrm{L})$ with $30 \mu \mathrm{L}$ of thiazolyl blue tetrazolium bromide $(5 \mathrm{mg} / \mathrm{mL})$ dissolved in phosphate buffered saline. After incubation for $4 \mathrm{~h}$, the medium was gently aspirated, and the formazan crystals were dissolved in $50 \mu \mathrm{L}$ of DMSO and kept in the dark for $15 \mathrm{~min}$ at room temperature. The absorbance was measured spectrophotometrically at $570 \mathrm{~nm}$ on a microplate reader (Synergy Multi-Mode Reader, BioTek).
Inhibition of soybean 15-lipoxygenase (15-LOX) enzyme The assay was performed according to the procedure of Pinto et al. [25] with slight modifications to the microtitre plate format. The assay is based on the formation of the complex $\mathrm{Fe}^{3}$ ${ }^{+} / x y l e n o l$ orange with absorption at $560 \mathrm{~nm}$. The 15-lipoxygenase (15-LOX) enzyme from soybean (Sigma Aldrich, Germany) was incubated with different concentrations of extracts or quercetin used as standard inhibitor (both serially diluted from 0.78 to $100 \mu \mathrm{g} / \mathrm{mL}$ ) at $25^{\circ} \mathrm{C}$ for $5 \mathrm{~min}$. The substrate, linoleic acid (final concentration, $140 \mu \mathrm{M}$ ) prepared in Tris- $\mathrm{HCl}$ buffer $(50 \mathrm{mM}, \mathrm{pH} 7.4)$, was added and the mixture was incubated at $25^{\circ} \mathrm{C}$ for $20 \mathrm{~min}$ in the dark. The assay was terminated by the addition of $100 \mu \mathrm{L}$ of FOX reagent [sulfuric acid $(30 \mathrm{mM})$, xylenol orange $(100 \mu \mathrm{M})$, iron (II) sulfate $(100 \mu \mathrm{M})$ in methanol/water (9:1)]. The negative control was made of the enzyme 15-LOX solution, buffer, substrate and FOX reagent while the blanks contained the enzyme 15-LOX and buffer, but the substrate was added after the FOX reagent. The lipoxygenase inhibitory activity was evaluated by calculating the percentage of the inhibition of hydroperoxide production from the changes in absorbance values at $560 \mathrm{~nm}$ after 30 min at $25^{\circ} \mathrm{C}$ as indicated in the formula (2) below.

$$
\begin{aligned}
& \text { Percentage LO X inhibition (\%) } \\
& =\frac{\text { Absorbance (control)-Absorbance (sample) }}{\text { Absorbance (control) }}
\end{aligned}
$$

The $\mathrm{IC}_{50}$ values of extracts or quercetin, which represent the concentration leading to $50 \%$ inhibition were calculated using the non-linear regression curve of the percentage (15-LOX) inhibition against the logarithm of concentrations tested.

\section{Cytotoxicity assay \\ Cell culture}

The four cancer cell lines (MCF-7: human breast adenocarcinoma cells; HeLa: human cervix adenocarcinoma cells; Caco-2: human epithelial colorectal adenocarcinoma cells; A549: human epithelial lung adenocarcinoma cells) were obtained from the American Type Culture Collection (ATCC) (Rockville, $\mathrm{MD}$, USA). These cells were grown at $37{ }^{\circ} \mathrm{C}$ with $5 \% \mathrm{CO}_{2}$ in a humidified environment in Dulbecco's Modified Eagle's Medium (DMEM) high glucose $(4.5 \mathrm{~g} / \mathrm{L})$ containing L-glutamine $(4 \mathrm{mM})$ and sodium pyruvate (Separations, RSA) supplemented with $10 \%(v / v)$ fetal bovine serum (Capricorn Scientific Gmbh, South America). Non-cancerous African green monkey (Vero) kidney cells (obtained from ATCC) were maintained at $37^{\circ} \mathrm{C}$ and $5 \% \mathrm{CO}_{2}$ in a humidified environment in Minimal Essential Medium (MEM) containing L-glutamine (Lonza, Belgium) supplemented with 5\% fetal bovine serum (Capricorn Scientific Gmbh, South America) and 1\% gentamicin (Virbac, RSA). 


\section{Cell treatment and assay procedure}

The cells were seeded at a density of $10^{4}$ cells per well on 96-well microtitre plates, and were left overnight to allow attachment. After this, the cells were treated with different concentrations of extracts dissolved in dimethyl sulfoxide (DMSO), and further diluted in fresh culture medium. In each experiment, the highest concentration of DMSO (negative control) in the medium was $0.5 \%$. After incubation for $48 \mathrm{~h}$ at $37{ }^{\circ} \mathrm{C}$ with $5 \% \mathrm{CO}_{2}$, the culture medium was discarded, and replaced by fresh medium $(200 \mu \mathrm{L})$ with $30 \mu \mathrm{L}$ of thiazolyl blue tetrazolium bromide $(5 \mathrm{mg} / \mathrm{mL})$ dissolved in phosphate buffered saline. The medium was gently aspirated after $4 \mathrm{~h}$ of incubation, and the formazan crystals were dissolved in $50 \mu \mathrm{L}$ of DMSO, and kept in the dark for $15 \mathrm{~min}$ at room temperature. The absorbance was measured spectrophotometrically at $570 \mathrm{~nm}$ on a microplate reader (Synergy Multi-Mode Reader, BioTek). The viability of cells treated with the extracts was calculated for each concentration compared to the negative control. The $50 \%$ inhibitory concentrations $\left(\mathrm{IC}_{50}\right)$ for cancer cell lines and the $50 \%$ lethal concentrations $\left(\mathrm{LC}_{50}\right)$ for the non-cancerous cells were determined by plotting the non-linear regression curve of percentage of cell survival versus the logarithm of concentrations of each extract. The selectivity index (SI) values were calculated for each extract by dividing the $\mathrm{LC}_{50}$ of the non-cancerous cell against the $\mathrm{IC}_{50}$ of each cancer cell type in the same units.

\section{Evaluation of the induction of apoptosis on cancer cells}

The induction of apoptosis by the most active extracts from each plant was evaluated by measuring the caspase $3 / 7$ activity on different cancer cell lines with the Caspase-Glo ${ }^{\oplus}$ 3/7 assay kit (Promega). All four cancer cell lines were seeded at a density of $10^{4}$ cells per well on 96-well microtitre plates, and were allowed to adhere overnight. These cells were treated with the extracts at different concentrations $\left(1 / 2 \times \mathrm{IC}_{50}, \mathrm{IC}_{50}\right.$ and $2 \times$ $\mathrm{IC}_{50}$ ) or DMSO $(0.5 \%)$ as negative control, and the plates were incubated at $37{ }^{\circ} \mathrm{C}$ with $5 \% \mathrm{CO}_{2}$ for $24 \mathrm{~h}$. After treatment, the Caspase-Glo $3 / 7$ was prepared according to manufacturer's guidelines, and $100 \mu \mathrm{L}$ of the reagent was added per well and incubated for $1 \mathrm{~h}$ at room temperature in the dark. Following this incubation, the luminescence was measured on a microplate reader (Synergy Multi-Mode Reader, BioTek). The data was analysed, and expressed as percentage of the untreated cells (control) and fold change.

\section{Statistical analysis}

All experiments were performed in triplicate, and the results are presented as mean \pm standard error of mean (SEM) values. Statistical analysis was carried out with GraphPad Instat 3.0 software. The Student-NewmanKeuls test was used to determine $P$-values for the differences observed between the extracts while Dunnett's test was used to compare the extracts with the control. Results were considered significantly different when $P<0.05$.

\section{Results}

Yield of extraction and phytochemical content of crude extracts

The voucher specimen numbers (PRU) and the yield of extraction of each plant material in a particular solvent are summarized in Table 1. The highest yield of extraction was observed with $C$. pseudopulchellus with all the three solvents used. Extraction with ethanol had the highest yield of extraction among the plant species. The phytochemical content of all extracts is presented in Table 2, and significant differences have been noted between total phenolic content (TPC) and total flavonoid content (TFC) of the plant materials extracted with the three solvents used. Organic solvents (acetone and ethanol) extracted more of these compounds compared to water. The acetone leaf extract of $C$. gratissimus had the highest TPC with $222.29 \mathrm{mgGAE} / \mathrm{g}$ whereas the highest TFC was obtained with the acetone and ethanol leaf extracts of C. sylvaticus with 82.76 and $84.54 \mathrm{mgQE} / \mathrm{g}$ respectively.

\section{Antioxidant activity of extracts}

Two antioxidant assays which involved the measurement of colour disappearance caused by free radicals such as DPPH and ABTS were used. As expected, the free radical scavenging activity of the extracts was concentration-dependent (data not shown) and the $\mathrm{IC}_{50}$ values determined are presented in Table 2 . The antioxidant activity varies within extracts from the same plant and between extracts from different plants. It should be noted that a lower $\mathrm{IC}_{50}$ value indicates a stronger antioxidant potency of the sample tested. Therefore, the ethanol leaf extracts from all the three plants have good antioxidant potency when compared with acetone and water extracts from the same plant. Among all the extracts from the three plants, the ethanol leaf extract of C. gratissimus had the highest antioxidant potency with $\mathrm{IC}_{50}$ values of 32.18 and $34.95 \mu \mathrm{g} / \mathrm{mL}$ respectively for the DPPH and ABTS radical scavenging activity. Ascorbic acid and trolox, known as potent antioxidant compounds, had the best antioxidant potency with $\mathrm{IC}_{50}$ values of 1.92 and $3.92 \mu \mathrm{g} / \mathrm{mL}$ (ascorbic acid); 2.21 and $4.64 \mu \mathrm{g} / \mathrm{mL}$ (trolox) respectively for the DPPH and ABTS radical scavenging activity (Table 2).

\section{Anti-inflammatory activity of extracts}

The anti-inflammatory activity of leaf extracts was determined using the nitric oxide (NO) and 15-lipoxygenase (15-LOX) inhibitory assays.

Nitric oxide inhibitory effect of extracts on LPS-stimulated RAW 264.7 macrophages

All the extracts from the three Croton species had inhibitory activity on NO production in a concentration-dependent manner (Fig. 1a and b). Water leaf extracts of the three plants had the lowest NO inhibitory effect except for the water extract from C. gratissimus that had a good inhibitory 
Table 2 Phytochemical content, antioxidant activity, nitric oxide and 15-lipoxygenase inhibition of different extracts from Croton species and positive controls

\begin{tabular}{|c|c|c|c|c|c|c|c|}
\hline \multirow[t]{2}{*}{ Plant name } & \multirow[t]{2}{*}{ Extracts } & \multicolumn{2}{|l|}{ Phytochemicals } & \multicolumn{4}{|l|}{$\mathrm{I}_{50}(\mu \mathrm{g} / \mathrm{mL})$} \\
\hline & & TPC (mgGAE/g) & TFC (mgQE/g) & $\mathrm{DPPH}$ & ABTS & NO & 15-LOX \\
\hline \multirow[t]{3}{*}{ Croton gratissimus } & CGA & $222.29 \pm 3.90^{\mathrm{a}}$ & $43.35 \pm 0.26^{\mathrm{a}}$ & $217.64 \pm 3.46^{\mathrm{a}}$ & $170.51 \pm 4.95^{\mathrm{a}}$ & $49.24 \pm 0.93^{\mathrm{a}}$ & $10.97 \pm 1.19^{\mathrm{a}}$ \\
\hline & CGE & $180.61 \pm 1.74^{b}$ & $44.39 \pm 0.27^{a}$ & $32.18 \pm 2.11^{b}$ & $34.95 \pm 0.81^{b}$ & $51.93 \pm 0.11^{\mathrm{a}}$ & $2.58 \pm 0.02^{b}$ \\
\hline & CGW & $121.92 \pm 1.78^{c}$ & $29.50 \pm 1.21^{b}$ & $>500$ & $>500$ & $88.90 \pm 0.57^{b}$ & $>100$ \\
\hline \multirow[t]{3}{*}{ Croton pseudopulchellus } & CPA & $124.05 \pm 2.00^{c}$ & $35.88 \pm 0.40^{c}$ & $220.34 \pm 4.98^{\mathrm{a}}$ & $176.94 \pm 2.26^{\mathrm{a}}$ & $34.64 \pm 0.06^{c}$ & $2.64 \pm 0.23^{b}$ \\
\hline & CPE & $84.28 \pm 1.52^{d}$ & $35.62 \pm 0.36^{c}$ & $205.96 \pm 3.66^{\mathrm{a}}$ & $144.01 \pm 2.28^{c}$ & $53.49 \pm 0.47^{\mathrm{a}}$ & $0.57 \pm 0.17^{c}$ \\
\hline & CPW & $35.10 \pm 1.44^{e}$ & $15.97 \pm 0.87^{d}$ & $>500$ & $>500$ & $>100$ & $>100$ \\
\hline \multirow[t]{3}{*}{ Croton sylvaticus } & CSA & $112.34 \pm 1.29^{c}$ & $82.76 \pm 1.57^{\mathrm{e}}$ & $285.64 \pm 2.81^{c}$ & $165.84 \pm 7.91^{a}$ & $68.28 \pm 0.32^{d}$ & $11.64 \pm 1.26^{\mathrm{a}}$ \\
\hline & CSE & $180.88 \pm 1.93^{b}$ & $84.54 \pm 1.85^{e}$ & $252.19 \pm 2.11^{c}$ & $134.96 \pm 7.83^{c}$ & $78.91 \pm 2.19^{d}$ & $2.12 \pm 0.37^{b}$ \\
\hline & CSW & $99.27 \pm 0.18^{f}$ & $26.06 \pm 0.96^{b}$ & $>500$ & $>500$ & $>100$ & $>100$ \\
\hline \multirow[t]{3}{*}{ Positive controls } & Ascorbic acid & ND & ND & $1.92 \pm 0.08^{d}$ & $3.92 \pm 0.24^{d}$ & ND & ND \\
\hline & Trolox & ND & ND & $2.21 \pm 0.24^{d}$ & $4.64 \pm 0.46^{d}$ & ND & ND \\
\hline & Quercetin & ND & ND & ND & ND & $5.82 \pm 0.63^{e}$ & $24.60 \pm 0.49^{d}$ \\
\hline
\end{tabular}

Data are presented as means of triplicate measurements \pm standard error, superscript letters a-f represent statistical difference between data obtained, and for each parameter within a column of the above table, data with different letters mean significantly different at $p<0.05$ while data with same letters are statistically not different.; $\mathrm{ND}=$ Not Determined. IC $\mathrm{S}_{50}$ : concentration required to inhibit the activity by $50 \%$ compared to untreated controls. CGA, CGE and CGW represent respectively acetone, ethanol and water extracts of Croton gratissimus. CPA, CPE and CPW represent respectively acetone, ethanol and water extracts of Croton pseudopulchellus. CSA, CSE and CSW represent respectively acetone, ethanol and water extracts of Croton sylvaticus. TPC: total phenolic content (mg of gallic acid equivalent per gram of extract) and TFC: total flavonoid content (mg of quercetin equivalent per gram of extract). DPPH: 2,2-diphenyl-1-picrylhydrazyl radical, ABTS: 2,2'-azino-bis (3-ethylbenzothiazoline-6-sulfonic acid) radical, NO: nitric oxide, 15-LOX: 15-lipoxygenase

activity. Acetone and ethanol leaf extracts of the plants had the highest NO inhibitory activity compared with their respective water leaf extracts. The $\mathrm{IC}_{50}$ values were calculated, and are presented in Table 2. Acetone leaf extracts from the three plants had the lowest $\mathrm{IC}_{50}$ values, which are not significantly different from the $\mathrm{IC}_{50}$ values obtained for the ethanol leaf extracts. However, the acetone leaf extract of $C$. pseudopulchellus had an $\mathrm{IC}_{50}$ value $(34.64 \mu \mathrm{g} / \mathrm{mL})$ significantly $(P<0.05)$ lower than the $\mathrm{IC}_{50}$ of the ethanol extract $(53.49 \mu \mathrm{g} / \mathrm{mL})$ from the same plant. The acetone leaf extract of C. pseudopulchellus therefore had the highest NO inhibitory potency. Quercetin, used as positive control, had the highest NO inhibitory potency with $\mathrm{IC}_{50}$ of $5.82 \mu \mathrm{g} / \mathrm{mL}$.

The cell viability of LPS-stimulated RAW 264.7 macrophages after treatment with the extracts and quercetin is presented in Fig. 1c. The acetone and ethanol leaf extracts as well as quercetin were slightly cytotoxic on LPS-stimulated RAW 264.7 macrophages with percentage of cell viability varying between 62 and 96\%. The water leaf extracts were less cytotoxic with cell viability greater than $76 \%$ at the highest concentration $(100 \mu \mathrm{g} / \mathrm{mL})$ tested.

\section{Lipoxygenase inhibitory activity of extracts}

The ferrous oxidation-xylenol orange (FOX) assay was used to determine the 15-lipoxygenase inhibitory activity of different extracts from the three Croton species, and the $\mathrm{IC}_{50}$ values were determined using the non-linear regression curves (Additional file 1: Figure S1) and the results are presented in Table 2 . All the extracts except the water extracts had better inhibitory activity against 15-lipoxygenase when compared to the positive control (quercetin). The $\mathrm{IC}_{50}$ values of the active extracts (acetone and ethanol) from the three plants varied between 0.57 and $11.64 \mu \mathrm{g} / \mathrm{mL}$ which is significantly $(P<0.05)$ different from quercetin $(24.60 \mu \mathrm{g} / \mathrm{mL})$. Ethanol leaf extracts were more active than acetone leaf extracts from the same plant species, thus suggesting that ethanol extracted more anti-lipoxygenase compounds than acetone. The highest lipoxygenase inhibitory activity was obtained with the ethanol leaf extract of C. pseudopulchellus ( $\mathrm{IC}_{50}$ of $0.57 \mu \mathrm{g} / \mathrm{mL}$ ).

\section{Selective cytotoxic effect of extracts on a non-cancerous cell versus cancerous cells}

Different extracts were tested for cytotoxicity against four cancerous (A549, Caco-2, HeLa and MCF-7) cell types as well as the non-cancerous African green monkey (Vero) kidney cells, and the graphs of cell viability against the concentrations tested are presented in Additional file 2: Figure S2, Additional file 3: Figure S3, Additional file 4: Figure S4, Additional file 5: Figure S5 and Additional file 6: Figure S6 respectively. The $\mathrm{LC}_{50}$ and $\mathrm{IC}_{50}$ values of extracts were determined from concentration-dependent graphs, and are presented in Table 3. Water leaf extracts had the lowest cytotoxic effect on both non-cancerous and cancerous cells with $\mathrm{LC}_{50}$ or $\mathrm{IC}_{50}$ greater than $533.33 \mu \mathrm{g} / \mathrm{mL}$ and $200 \mu \mathrm{g} / \mathrm{mL}$, respectively. An exception was observed with the water leaf extract of $C$. sylvaticus that had good cytotoxicity $\left(\mathrm{IC}_{50}\right.$ of $45.62 \mu \mathrm{g} / \mathrm{mL}$ ) on MCF-7 cells with a promising selectivity index greater than 21.92 (see Table 3). On the other hand, ethanol leaf extracts of C. pseudopulchellus and C. sylvaticus were more cytotoxic on both 

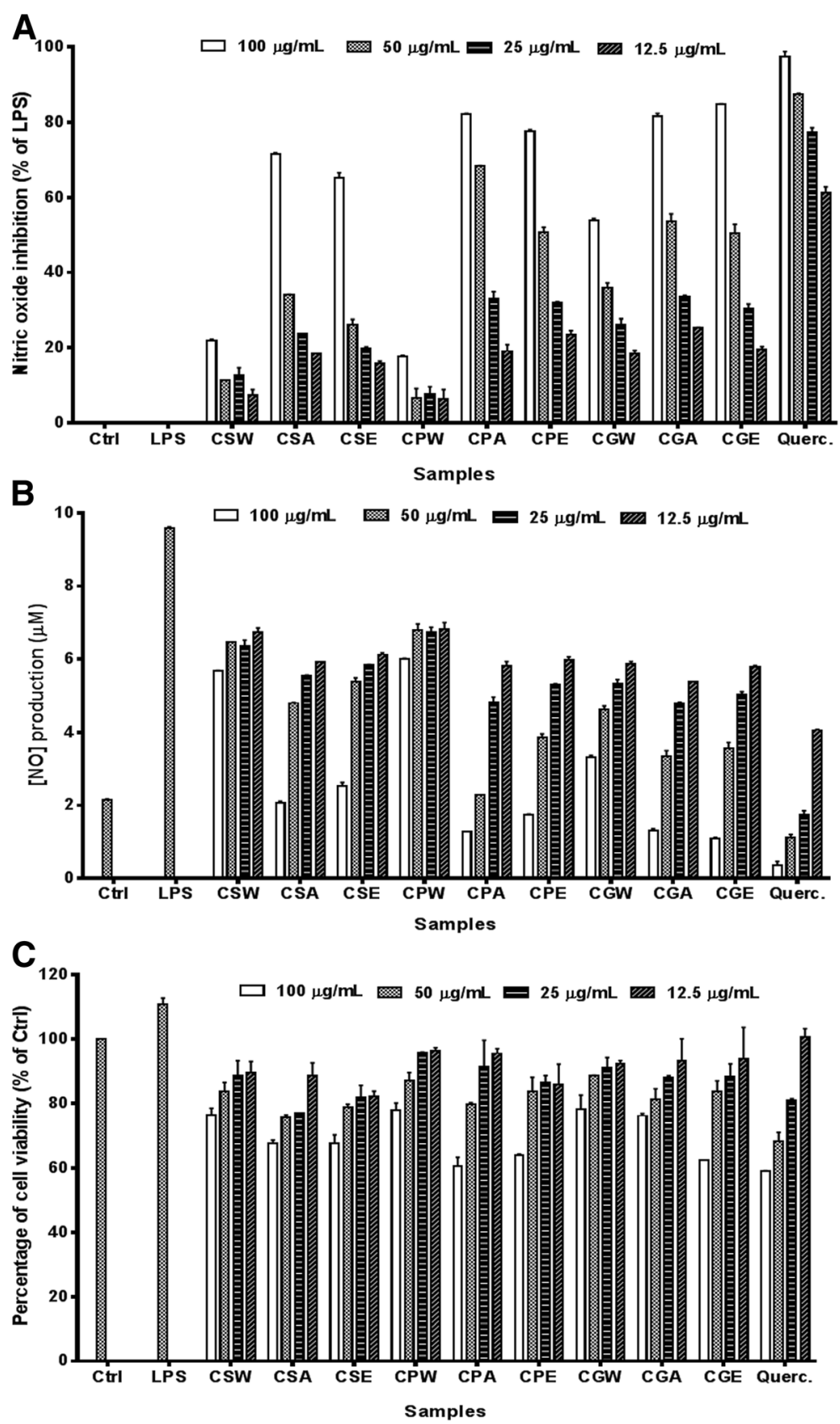

Fig. 1 Activities of the extracts from three Croton species on the percentage of nitric oxide inhibition (a), nitric oxide production (b) and cell viability (c) on LPS-stimulated RAW 264.7 macrophages. Data are presented as means of triplicate measurements \pm standard error. CSA, CSE and CSW represent respectively acetone, ethanol and water extracts of Croton sylvaticus. CPA, CPE and CPW represent respectively acetone, ethanol and water extracts of Croton pseudopulchellus. CGA, CGE and CGW represent respectively acetone, ethanol and water extracts of Croton gratissimus. Ctrl: control group (0.5\% DMSO); LPS: lipopolysaccharide

non-cancerous and cancerous cells with lowest $\mathrm{LC}_{50}$ or $\mathrm{IC}_{50}$ values obtained against all cell lines. Acetone and ethanol leaf extracts of C. pseudopulchellus and C. sylvaticus had the highest cytotoxic activity on the non-cancerous cells with $\mathrm{LC}_{50}$ varying between 7.86 and $48.19 \mu \mathrm{g} / \mathrm{mL}$ while the acetone and ethanol extracts of $C$. gratissimus were less cytotoxic on these cell lines with $\mathrm{LC}_{50}$ varying between 152.30 and $462.88 \mu \mathrm{g} /$
$\mathrm{mL}$. The selectivity index (SI) values indicated that the acetone and ethanol extracts of $C$. gratissimus were most selective with SI ranging between 1.91 and 6.25 (see Table 3). In addition, the ethanol leaf extract and acetone leaf extract of $C$. sylvaticus were highly selective against A549 and MCF-7 cells with SI of 4.70 and 2.12, respectively. The same observation was made with the acetone leaf extract of $C$. pseudopulchellus which had 
Table 3 Cytotoxic effect $\left(\mathrm{IC}_{50}\right.$ and $\left.\mathrm{LC}_{50}\right)$ and the selectivity index $(\mathrm{SI})$ of different extracts from Croton species and reference drug (doxorubicin hydrochloride) on cancerous cell lines versus a non-cancerous cell line

\begin{tabular}{|c|c|c|c|c|c|c|c|c|c|c|}
\hline \multirow[t]{2}{*}{ Plant Name } & \multirow[t]{2}{*}{ Extracts } & \multirow{2}{*}{$\begin{array}{l}\mathrm{LC}_{50}(\mu \mathrm{g} / \mathrm{mL}) \\
\text { Vero }\end{array}$} & \multicolumn{8}{|c|}{$\mathrm{IC}_{50}(\mu \mathrm{g} / \mathrm{mL})$ and Selectivity index $=\mathrm{LC}_{50} / \mathrm{IC}_{50}$} \\
\hline & & & A549 & $\mathrm{SI}$ & Caco-2 & $\mathrm{SI}$ & HeLa & $\mathrm{SI}$ & MCF-7 & $\mathrm{SI}$ \\
\hline \multirow[t]{3}{*}{ Croton gratissimus } & CGA & $462.88 \pm 7.71^{\mathrm{a}}$ & $97.46 \pm 2.20^{\mathrm{a}}$ & 4.75 & $74.05 \pm 5.79^{\mathrm{a}}$ & 6.25 & $78.21 \pm 0.17^{\mathrm{a}}$ & 5.91 & $83.74 \pm 2.06^{\mathrm{a}}$ & 5.52 \\
\hline & CGE & $152.30 \pm 3.68^{\mathrm{b}}$ & $79.60 \pm 2.32^{b}$ & 1.91 & $48.46 \pm 3.47^{b}$ & 3.14 & $73.78 \pm 4.12^{\mathrm{a}}$ & 2.06 & $39.75 \pm 2.49^{b}$ & 3.83 \\
\hline & CGW & $533.33 \pm 13.21^{\mathrm{a}}$ & $>200$ & $<2.66$ & $>200$ & $<2.66$ & $>200$ & $<2.66$ & $>200$ & $<2.66$ \\
\hline \multirow[t]{3}{*}{ Croton pseudopulchellus } & CPA & $48.19 \pm 5.27^{c}$ & $36.54 \pm 1.81^{c}$ & 1.31 & $112.74 \pm 4.26^{c}$ & 0.42 & $128.69 \pm 21.97^{b}$ & 0.37 & $24.65 \pm 2.37^{c}$ & 1.95 \\
\hline & CPE & $7.86 \pm 1.47^{d}$ & $23.78 \pm 1.41^{d}$ & 0.33 & $36.24 \pm 2.34^{d}$ & 0.21 & $63.79 \pm 1.02^{c}$ & 0.12 & $13.54 \pm 1.18^{d}$ & 0.58 \\
\hline & CPW & $>1000$ & $>200$ & ND & $>200$ & ND & $>200$ & ND & $>200$ & ND \\
\hline \multirow[t]{3}{*}{ Croton sylvaticus } & CSA & $27.92 \pm 0.62^{e}$ & $32.78 \pm 2.55^{c}$ & 0.85 & $150.63 \pm 8.79^{e}$ & 0.18 & $169.09 \pm 13.05^{b}$ & 0.16 & $13.13 \pm 2.76^{d}$ & 2.12 \\
\hline & CSE & $8.23 \pm 0.44^{d}$ & $1.75 \pm 0.62^{e}$ & 4.70 & $103.73 \pm 1.47^{c}$ & 0.08 & $106.52 \pm 4.50^{b}$ & 0.07 & $6.02 \pm 1.60^{e}$ & 1.36 \\
\hline & CSW & $>1000$ & $>200$ & ND & $>200$ & ND & $>200$ & ND & $45.62 \pm 5.69^{b}$ & $>21.92$ \\
\hline \multicolumn{2}{|l|}{ Doxorubicin $(\mu \mathrm{M})$} & $1.90 \pm 0.15^{f}$ & $1.30 \pm 0.06^{f}$ & 1.46 & $1.08 \pm 0.18^{f}$ & 1.75 & $2.17 \pm 0.08^{d}$ & 0.87 & $1.11 \pm 0.03^{f}$ & 1.71 \\
\hline
\end{tabular}

Data are presented as means of triplicate measurements \pm standard error; superscript letters a-f represent statistical difference between data obtained, and for each cell line within a column of the above table, data with different letters mean significantly different at $p<0.05$ while data with same letters are statistically not different. $\mathrm{ND}=$ Not Determined. $\mathrm{IC}_{50}$ : concentration required to inhibit the cell growth by $50 \%$ compared to untreated controls. $\mathrm{SI}$ is the selectivity index which is determined for each extract by dividing the $\mathrm{LC}_{50}$ on the non-cancerous cell by the $\mathrm{IC}_{50}$ on each cancer cell in the same units. CGA, CGE and CGW represent respectively acetone, ethanol and water extracts of Croton gratissimus. CPA, CPE and CPW represent respectively acetone, ethanol and water extracts of Croton pseudopulchellus. CSA, CSE and CSW represent respectively acetone, ethanol and water extracts of Croton sylvaticus

SI of 1.31 and 1.95 against A549 and MCF-7 cells, respectively. On the contrary, the ethanol leaf extract of C. pseudopulchellus was less selective on non-cancerous cells with the lowest SI values ranging between 0.12 and 0.58 against all cancerous cells. Similarly, acetone and ethanol leaf extracts of C. sylvaticus were less selective with SI varying between 0.07 and 0.18 against Caco-2 and HeLa cells. Doxorubicin hydrochloride, the positive control, was highly cytotoxic on all cells with SI ranging between 0.87 and 1.75 .

\section{Induction of caspase-dependent apoptosis by active extracts on cancerous cells}

In this assay, acetone leaf extracts of the three Croton species were used based on their high selectivity indexes or lower cytotoxicity to non-cancerous cells compared to other extracts. The activation of caspase- 3 and -7 enzymes was differentially observed in all the four cancerous cells treated with the active extracts compared to the untreated controls (see Fig. 2). Caspase -3 and -7 enzymes were better activated after treatment with acetone leaf extracts of the three plants on HeLa and MCF-7 cells. The activation of these enzymes was also observed on A549 and Caco-2 cells only after treatment with the acetone leaf extracts of $C$. pseudopulchellus and $C$. gratissimus (Fig. $2 \mathrm{~b}$ and $\mathrm{c})$. These two extracts significantly $(P<0.05)$ induced caspase -3 and -7 activity in all cancerous cells at concentrations of $1 / 2 \times \mathrm{IC}_{50}$ (1.24 to 1.56 -fold change). A non-significant increase of the activity of caspase -3 and -7 was noted after treatment with acetone leaf extracts of $C$. sylvaticus on A549 and MCF-7 cells (1.10 to 1.13-fold change). The acetone leaf extract of $C$. gratissimus induced activation of caspase -3 and -7 activity in a concentration-dependent manner on HeLa cells (Fig. 2c), and the highest induction (1.83-fold change) was obtained at the concentration of $2 \times \mathrm{IC}_{50}$.

\section{Discussion}

Our study aimed to evaluate the antioxidant, anti-inflammatory and cytotoxic activities of three Croton species. The ethanol leaf extracts of the three plants were highly active in all experiments (except the NO inhibitory activity) compared to acetone and water leaf extracts. These results suggested that the antioxidant, anti-inflammatory and cytotoxic compounds extracted from the three plants are more concentrated in the ethanol leaf extract than in the acetone or water leaf extracts. We also investigated the potential relationship between the antioxidant, anti-inflammatory and cytotoxic activities of the active ethanol and acetone extracts. This relationship was analysed by determining the Pearson correlation coefficients ( $r$ ) after plotting a linear curve with $\mathrm{IC}_{50}$ values of each cancer cell on the $\mathrm{y}$-axis against phytochemical content or $\mathrm{IC}_{50}$ values of the antioxidant power (DPPH, ABTS) and anti-inflammatory activity (NO, 15-LOX) on the $\mathrm{x}$-axis (Table 4). A linear correlation $(\mathrm{r}<0.5)$ existed between antioxidant, anti-inflammatory and cytotoxic activities, although this correlation was considered to be less strong. In fact, free radicals are well known to play a major role in the development of oxidative stress that can lead to many illnesses including cardiovascular diseases, diabetes, inflammation, degenerative diseases, and cancer [26]. Nitric oxide (NO), a molecule playing a crucial role in inflammatory response, can react with free radicals such as superoxides to produce peroxynitrites that can cause irreversible damage to cell membranes leading to the promotion of tumor growth and proliferation [27]. In addition, natural inhibitors of lipoxygenases have been shown to suppress carcinogenesis and tumor growth in a number of experimental models [28]. Moreover, several scientific reports have suggested that antioxidant and anti-inflammatory agents could be beneficial in the prevention and treatment of cancer [29]. Our results therefore suggest that the antioxidant 


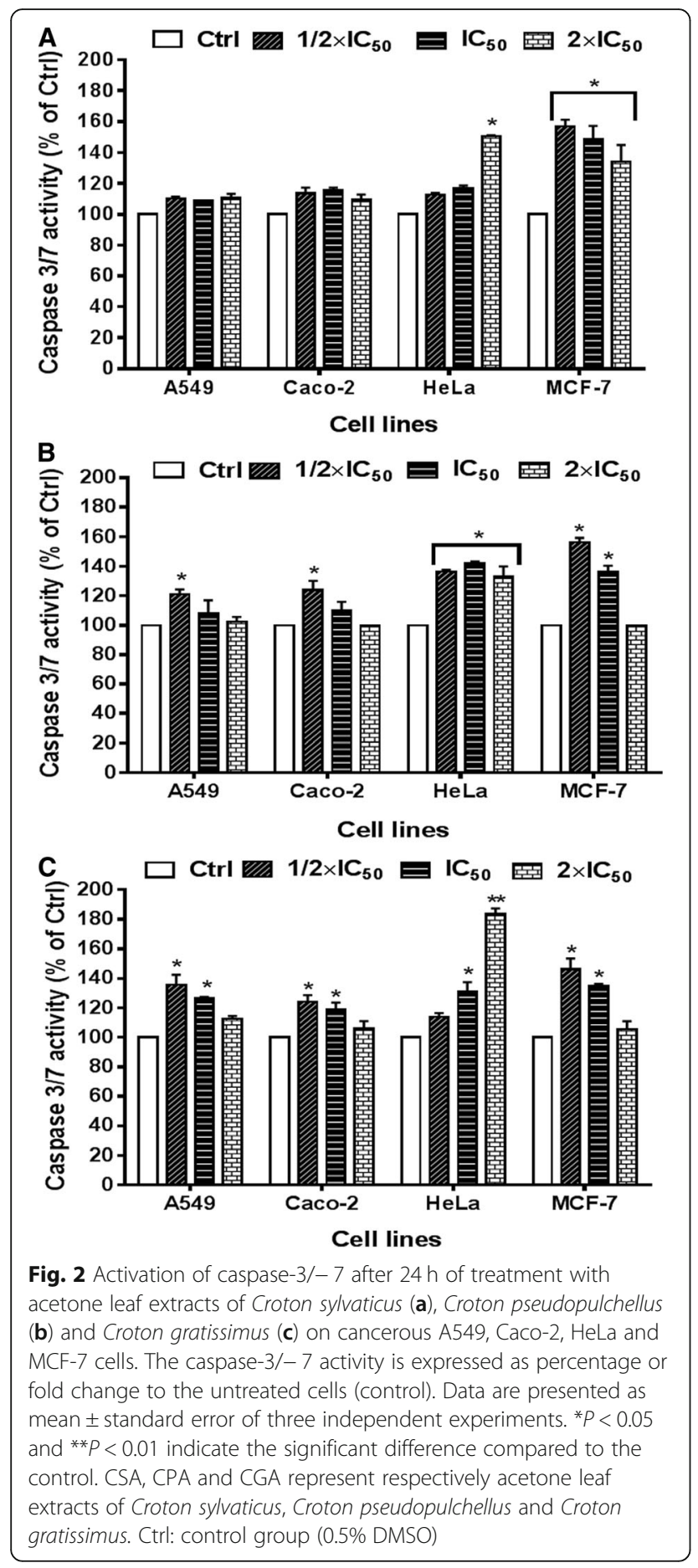

or anti-inflammatory activities of extracts may contribute moderately to their cytotoxic activity. Phenolics and flavonoids are known for their contribution either directly or indirectly to the cytotoxic activity. In our study, we noted that the acetone and ethanol extracts of $C$. gratissimus which had the highest total phenolic contents (222.29 and $180.61 \mathrm{mgGAE} / \mathrm{g}$ respectively) were selectively cytotoxic to cancerous cells compared to non-cancerous. Indeed, due to their anti- and pro-oxidant
Table 4 Correlation between phytochemical content, antioxidant, anti-inflammatory and antiproliferative activity of active extracts

\begin{tabular}{lllllll}
\hline \multirow{2}{*}{$\begin{array}{l}\text { Cell } \\
\text { lines }\end{array}$} & \multicolumn{6}{l}{ Pearson correlation coefficient $(r)$} \\
\cline { 2 - 7 } & TPC & TFC & DPPH & ABTS & NO & $15-$ LOX \\
\hline A549 & 0.3530 & 0.2404 & 0.2850 & 0.4030 & 0.2525 & 0.1935 \\
CaCO-2 & 0.0143 & 0.4529 & 0.4545 & 0.2758 & 0.2820 & 0.2798 \\
HeLa & 0.0920 & 0.3724 & 0.3582 & 0.2043 & 0.2847 & 0.2251 \\
MCF-7 & 0.3111 & 0.2399 & 0.0800 & 0.0003 & 0.2027 & 0.2341
\end{tabular}

Correlation coefficients were determined by plotting a linear curve with $\mathrm{IC}_{50}$ values of extracts obtained for each cancer cell on the $y$-axis against the corresponding phytochemical content or $\mathrm{IC}_{50}$ values of the antioxidant power (DPPH, ABTS) and anti-inflammatory activity (NO, 15-LOX) on the x-axis. NO: nitric oxide, 15-LOX: 15-lipoxygenase. TPC: total phenolic content, TFC: total flavonoid content, DPPH: 2,2-diphenyl-1-picrylhydrazyl radical, ABTS: 2,2'-azinobis (3-ethylbenzothiazoline-6-sulfonic acid) radical

potential, phenolics (which also include flavonoids) may have cytotoxic activity against different human cancer cells with little or no effect on normal cells. This selectivity in the cytotoxicity properties of phenolics has strengthened interest in formulating novel and less toxic anticancer products based on these types of compounds [30, 31].

The goal of any chemotherapeutic treatment is to selectively attenuate or destroy pathogenic micro-organisms or cancerous cells with minimal side effects to the host cells [32]. This principle, known as selective toxicity, is the key to all chemotherapeutic treatment. In this study, the acetone and ethanol extracts of $C$. gratissimus were more selective with SI ranging between 1.91 and 6.25, and it therefore indicates that these extracts may be useful in the search for anticancer compounds. A cembranolide isolated from stem bark of Croton gratissimus had moderate activity against PEO1 and PEO1TaxR ovarian cancer cell lines [16]. In the present work, four cancerous (A549, Caco-2, HeLa, MCF-7) cells and a non-cancerous (Vero) cell line were used to evaluate the antiproliferative activity of the crude extracts from three Croton species. The use of these cancerous cells with the non-cancerous (Vero) cell line as cell models has been reported for comparison and determination of the selectivity indexes [33, 34]. However, the cytotoxic effect on this non-cancerous (Vero) cell line of animal origin needs to be confirmed on other non-cancerous cells of human origin. The selective toxicity of acetone and ethanol extracts of $C$. gratissimus also suggested that the active compounds interact with special cancer-associated receptors or cancer cell special molecule (not found in non-cancerous cells), thus activating some mechanisms that cause cancer cell death [35]. The activation of caspase -3 and -7 enzymes was observed in all four of the cancer cell types treated with the active extracts compared to the untreated cells, which therefore reveals that apoptosis has taken place in the treated cells. Indeed, caspases -3 , and -7 are known as "executioners" of apoptosis since they serve as substrates for initiator caspases in extrinsic or intrinsic apoptotic pathways [36]. It will be important to comprehensively investigate the mechanism of the 
activity, and this aspect will be addressed once the compounds responsible for the activity have been isolated. The aim of the current study was to explore the possibility that extracts have inhibitory activity on cancer cell growth.

According to the United States National Cancer Institute, a crude extract is generally considered to have in vitro cytotoxic activity if the $\mathrm{IC}_{50}$ is lower than $30 \mu \mathrm{g} / \mathrm{mL}$ [37]. Based on this statement, acetone and ethanol extracts of C. pseudopulchellus and C. sylvaticus were considered as more active on both cancerous A549 and MCF-7 cells. Differences in the selectivity indexes of these extracts on these two cancerous cells may be ameliorated through the isolation of active compounds which might reduce the toxic effects of the crude extracts. Studies are ongoing to isolate active compounds from these active extracts.

\section{Conclusion}

In summary, due to their selective toxicity between noncancerous and cancerous cells, with beneficial antioxidant and anti-inflammatory activities, the acetone and ethanol leaf extracts of Croton gratissimus may be useful against cancer and other oxidative stress related diseases. The isolation of active compounds from this extract will be of great interest to fully understand the mechanism of anticancer activity. In addition, acetone and ethanol extracts of C. pseudopulchellus and C. sylvaticus, which were cytotoxic to both cancerous and non-cancerous cells, may be further explored as sources of new cytotoxic compounds.

\section{Additional files}

Additional file 1: Figure S1. Non-linear regression curves for $I C_{50}$ determination of different extracts from Croton species in 15-lipoxygenase (15-LOX) inhibitory assay. CSA and CSE represent respectively acetone, ethanol and water extracts of Croton sylvaticus. CGA and CGE represent respectively acetone, ethanol and water extracts of Croton gratissimus. CPA and CPE represent respectively acetone, ethanol and water extracts of Croton pseudopulchellus. (TIF $109 \mathrm{~kb}$ )

Additional file 2: Figure S2. Concentration-dependent graph of A549 cell viability of different extracts from Croton species. Extracts were tested at concentrations between 200 and $6.25 \mu \mathrm{g} / \mathrm{mL}$; Ctrl: 0.5\% DMSO. (TIF $128 \mathrm{~kb}$ )

Additional file 3: Figure S3. Concentration-dependent graph of Caco-2 cell viability of different extracts from Croton species. Extracts were tested at concentrations between 200 and $6.25 \mu \mathrm{g} / \mathrm{mL}$; Ctrl: 0.5\% DMSO. (TIF 156 $\mathrm{kb})$

Additional file 4: Figure S4. Concentration-dependent graph of HeLa cell viability of different extracts from Croton species. Extracts were tested at concentrations between 200 and $6.25 \mu \mathrm{g} / \mathrm{mL}$; Ctrl: 0.5\% DMSO. (TIF $142 \mathrm{~kb}$ )

Additional file 5: Figure S5. Concentration-dependent graph of MCF-7 cell viability of different extracts from Croton species. Extracts were tested at concentrations between 200 and $6.25 \mu \mathrm{g} / \mathrm{mL}$; Ctrl: 0.5\% DMSO. (TIF $136 \mathrm{~kb}$ )

Additional file 6: Figure S6. Concentration-dependent graph of Vero cell viability of different extracts from Croton species. Extracts were tested at concentrations between 1000 and $50 \mu \mathrm{g} / \mathrm{mL}$ Ctrl: 0.5\% DMSO. (TIF $132 \mathrm{~kb}$ )

\section{Abbreviations}

ABTS: 2,2'-azino-bis (3-ethylbenzothiazoline-6-sulfonic acid; ATCC: American type culture collection; DMSO: Dimethyl sulphoxide; DPPH: 2,2-diphenyl-1picrylhydrazyl; FOX: Ferrous oxidation-xylenol orange; GAE: Gallic acid equivalent; $I C_{50}$ : Inhibitory concentration to $50 \%$ of cells; $L C_{50}$ : Lethal concentration to $50 \%$ of cells; LOX: Lipoxygenase; LPS: Lipopolysaccharide; MEM: Minimal essential medium; MTT: 3-(4,5-dimethylthiazol-2-yl)-2,5diphenyltetrazolium bromide; NO: Nitric oxide; QE: Quercetin equivalent; TFC: Total flavonoid content; TPC: Total phenolic content

\section{Acknowledgements}

Authors thank Dr. Tshepiso J. Makhafola from the University of South Africa for providing the cancerous cell lines. EMN is very grateful to the University of Pretoria for the postdoctoral fellowship.

\section{Funding}

This work was supported by the National Research Foundation (NRF), South Africa through the Incentive Funding for Rated Researchers (Lyndy J. McGaw). The funder had no implication in the design of the study, collection, analysis and interpretation of data; and in writing the manuscript; and the decision to submit the article for publication.

\section{Availability of data and materials}

The datasets used and/or analyzed during the current study are available from the corresponding author on reasonable request.

\section{Authors' contributions}

EMN initiated the project, conducted the assays and wrote the manuscript, JNE contributed to initiating the project and editing the manuscript, LJM supervised the research and edited the manuscript. All authors have read and approved the final manuscript.

\section{Ethics approval and consent to participate}

Not applicable.

\section{Consent for publication}

Not applicable.

\section{Competing interests}

The authors declare that they have no competing interests. Prof Jacobus N Eloff is a Section Editor and Prof Lyndy J McGaw is an Associate Editor of BMC Complementary and Alternative medicine.

\section{Publisher's Note}

Springer Nature remains neutral with regard to jurisdictional claims in published maps and institutional affiliations.

Received: 2 October 2017 Accepted: 7 November 2018

Published online: 14 November 2018

References

1. Gęgotek A, Nikliński J, Žarković N, Žarković K, Waeg G, Łuczaj W, Charkiewicz $\mathrm{R}$, Skrzydlewska E. Lipid mediators involved in the oxidative stress and antioxidant defence of human lung cancer cells. Redox Biol. 2016;9:210-9.

2. Liochev SI. Reactive oxygen species and the free radical theory of aging. Free Radic Biol Med. 2013;60:1-4.

3. Rahman K. Studies on free radicals, antioxidants, and co-factors. Clin Interv Aging. 2007;2(2):219-36.

4. Islam S, Samima N, Muhammad AK, Sakhawat Hossain A, Farhadul I, Proma K, Haque Mollah MN, Mamunur R, Golam S, Md Aziz AR, et al. Evaluation of antioxidant and anticancer properties of the seed extracts of Syzygium fruticosum Roxb. Growing in Rajshahi, Bangladesh. BMC Complement Altern Med. 2013;13.

5. Zhang Y-J, Gan R-Y, Li S, Zhou Y, Li A-N, Xu D-P, Li H-B. Antioxidant phytochemicals for the prevention and treatment of chronic diseases. Molecules. 2015;20:21138-56.

6. Wang $H$, Khor TO, Shu L, Su ZY, Fuentes F, Lee JH, Kong AN. Plants vs. cancer: a review on natural phytochemicals in preventing and treating cancers and their druggability. Anti Cancer Agents Med Chem. 2012;12(10):1281-305. 
7. Bartsch $\mathrm{H}$, Nair J. Chronic inflammation and oxidative stress in the genesis and perpetuation of cancer: role of lipid peroxidation, DNA damage, and repair. Langenbeck's Arch Surg. 2006;91:499-510.

8. Gonda TA, Tu S, Wang TC. Chronic inflammation, the tumor microenvironment and carcinogenesis. Cell Cycle. 2009;8:2005-13.

9. Reuter S, Gupta SC, Chaturvedi MM, Aggarwal BB. Oxidative stress, inflammation, and cancer: how are they linked? Free Radic Biol Med. 2010 49(11):1603-16.

10. Salatino A, Salatino MLF, Negri G. Traditional uses, chemistry and pharmacology of Croton species (Euphorbiaceae). J Braz Chem Soc. 2007;18(1):11-33.

11. Kapingu MC, Mbwambo ZH, Moshi MJ, Magadula JJ. Brine shrimp lethality of alkaloids from Croton sylvaticus Hoechst. East and Central African Journal of Pharmaceutical Sciences. 2012;15:35-7.

12. Ndhlala AR, Aderogba MA, Ncube B, Van Staden J. Anti-oxidative and cholinesterase inhibitory effects of leaf extracts and their isolated compounds from two closely related Croton species. Molecules. 2013;18:1916-32.

13. Langat M, Mulholland DA, Crouch N: New diterpenoids from Croton sylvaticus and Croton pseudopulchellus (Euphorbiaceae) and antiplasmodial screening of ent-kaurenoic acid. Planta Med 2008, 74(09):PB126.

14. Ngadjui BT, Abegaz BM, Keumedjio F, Folefoc GN, Kapche GW. Diterpenoids from the stem bark of Croton zambesicus. Phytochemistry. 2002;60(4):345-9.

15. Block S, Stevigny C, De Pauw-Gillet MC, de Hoffmann E, Llabres G, Adjakidje V, Quetin-Leclerca J. Ent-trachyloban-3beta-ol, a new cytotoxic diterpene from Croton zambesicus. Planta Med. 2002;68(7):647-9.

16. Mulholland DA, Langat MK, Crouch NR, Coley HM, Mutambi EM, Nuzillard JM. Cembranolides from the stem bark of the southern African medicinal plant, Croton gratissimus (Euphorbiaceae). Phytochemistry. 2010;71:1381-6.

17. Langat MK, Crouch NR, Smith PJ, Mulholland DA. Cembranolides from the leaves of Croton gratissimus. J Nat Prod. 2011;74:2349-55.

18. Lall N, Meyer JJ. In vitro inhibition of drug-resistant and drug-sensitive strains of Mycobacterium tuberculosis by ethnobotanically selected south African plants. J Ethnopharmacol. 1999;66(3):347-54.

19. Zhang Q, Zhang J, Shen J, Silva A, Dennis D, Barrow C. A simple 96-well microplate method for estimation of total polyphenol content in seaweeds. J Appl Phycol. 2006;18:445-50.

20. Lin J, Tang C. Determination of total phenolic and flavonoid contents in selected fruits and vegetables, as well as their stimulatory effects on mouse splenocyte proliferation. Food Chem. 2007;101:140-7.

21. Brand-Williams W, Cuvelier ME, Berset C. Use of a free radical method to evaluate antioxidant activity. Lebensmittel Wissenschaftund Technologie. 1995;28(1):25-30.

22. Re R, Pellegrini N, Proteggente A, Pannala A, Yang M, Rice-Evans C. Antioxidant activity applying an improved ABTS radical cation decolourization assay. Free Radic Biol Med. 1999;28:1057-60.

23. Dzoyem JP, Eloff JN. Anti-inflammatory, anticholinesterase and antioxidant activity of leaf extracts of twelve plants used traditionally to alleviate pain and inflammation in South Africa. J Ethnopharmacol. 2015;160:194-201.

24. Mosmann T. Rapid colorimetric assay for cellular growth and survival: application to proliferation and cytotoxicity assays. J Immunol Methods. 1983;65(1-2):55-63.

25. Pinto MC, Tejeda A, Duque AL, Macias P. Determination of lipoxygenase activity in plant extracts using a modified ferrous oxidation-xylenol orange assay. J Agric Food Chem. 2007;55(15):5956-9.

26. Ravipati AS, Zhang L, Koyyalamudi SR, Jeong SC, Reddy N, Bartlett J, Smith PT, Shanmugam K, Munch G, Wu MJ, et al. Antioxidant and anti-inflammatory activities of selected Chinese medicinal plants and their relation with antioxidant content. BMC Complement Altern Med. 2012;12:173.

27. Choudhari SK, Chaudhary M, Bagde S, Amol R Gadbail AR, Joshi V. Nitric oxide and cancer: a review. World Journal of Surgical Oncology. 2013; $11((118)): 11$

28. Goossens L, Pommery N, Henichart JP. COX-2/5-LOX dual acting antiinflammatory drugs in cancer chemotherapy. Curr Top Med Chem. 2007; 7(3):283-96

29. Dufour D, Pichette A, Mshvildadze V, Hébert M-EB, Lavoie S, Longtin A, Laprise C, Legault J. Antioxidant, anti-inflammatory and anticancer activities of methanolic extracts from Ledum groenlandicum Retzius. J Ethnopharmacol. 2007;111:22-8.

30. Sak K. Cytotoxicity of dietary flavonoids on different human cancer types. Pharmacogn Rev. 2014;8(16):122-46.

31. Batra P. Sharma A. Anti-cancer potential of flavonoids: recent trends and future perspectives. 3 Biotech. 2013;3:439-59.
32. Wink M. Medicinal plants: a source of anti-parasitic secondary metabolites. Molecules. 2012;17(11):12771-91.

33. Namvar F, Baharara J, Mahdi AA. Antioxidant and anticancer activities of selected Persian gulf algae. Ind J Clin Biochem. 2014;29(1):13-20.

34. Sasipawan M, Natthida W, Sahapat B. Anticancer effect of the extracts from Polyalthia evecta against human hepatoma cell line (HepG2). Asian Pac J Trop Biomed. 2012;2(5):368-74.

35. Chow KH, Sun RW, Lam JB, Li CK, Xu A, Ma DL, Abagyan R, Wang Y, Che CM. A gold(III) porphyrin complex with antitumor properties targets the Wnt/beta-catenin pathway. Cancer Res. 2010;70(1):329-37.

36. Olsson M, Zhivotovsky B. Caspases and cancer. Cell Death Differ. 2011;18(9):1441-9.

37. Singh G, Passsari AK, Leo W, Mishra VK, Subbarayan S, Singh BP, Kumar B, Kumar S, Gupta VK, Lalhlenmawia H, et al. Evaluation of phenolic content variability along with antioxidant, antimicrobial, and cytotoxic potential of selected traditional medicinal plants from India. Front Plant Sci. 2016;7:407.

\section{Ready to submit your research? Choose BMC and benefit from:}

- fast, convenient online submission

- thorough peer review by experienced researchers in your field

- rapid publication on acceptance

- support for research data, including large and complex data types

- gold Open Access which fosters wider collaboration and increased citations

- maximum visibility for your research: over $100 \mathrm{M}$ website views per year

At BMC, research is always in progress.

Learn more biomedcentral.com/submissions 